\title{
Renal tubular asidosis tipe I dengan anemia hemolitik stomatositosis
}

\author{
Rizkianto Imannual ${ }^{1}$, Harnavi Harun ${ }^{2}$ \\ 1. Program Studi Pendidikan Dokter Spesialis, Fakultas Kedokteran, Universitas Andalas; 2. Bagian \\ IImu Penyakit Dalam, RSUP dr. M. Djamil Padang
}

Korespondensi: Rizkianto Imannual; email: rizkiantoimannual@gmail.com

\begin{abstract}
Abstrak
Renal tubular acidosis (RTA) tipe I adalah sindrom klinik akibat kegagalan pengasaman urine oleh tubuli distal yang ditandai oleh asidosis metabolik, hipokalemia, hiperkloremia, sedangkan anion gap serum dan fungsi glomerulus normal. Anemia stomatositosis adalah tipe anemia hemolitik nonautoimun yang diakibatkan kelainan pada membran eritrosit yang ditandai dengan ditemukannya stomatosit pada gambaran darah tepi. Tujuan: melaporkan kasus RTA tipe I dengan anemia stomatositosis herediter. Kasus: Dilaporkan sebuah kasus, wanita 30 tahun dengan keluhan utama lemah pada keempat anggota gerak sejak 1 hari sebelum masuk rumah sakit. Pasien juga merasakan sesak nafas, poliuri, polidipsi, pucat, lemah dan letih. Keluhan telah dirasakan berulang sejak 5 tahun yang lalu. Pemeriksaan fisik: pasien sadar, kusmaul, anemis, tetraparesis. Pemeriksaan penunjang: laboratorium $\mathrm{Hb} 8,8 \mathrm{~g} / \mathrm{dL}$; normositik normokrom dengan sel target (+) sel stomatosit (+); Kalium 1,7 $\mathrm{mmol} / \mathrm{L}$; Khlorida $122 \mathrm{mmol} / \mathrm{L}$. Analisis gas darah: $\mathrm{pH} \mathrm{7,05;} \mathrm{HCO}_{3}{ }^{-} 6,9 \mathrm{mmol} / \mathrm{L}$. Urinalisis: $\mathrm{pH}$ urine 6,5; elektrolit urine; kalium 18,2 mmol; TTKG 13; anion gap serum 11,4; anion gap urine 16,2. Diberikan substitusi kalium dan bikarbonat intravena. Pasien mengalami perbaikan gejala setelah di terapi. Simpulan: Perlu diberikan terapi substitusi kalium dan alkali seumur hidup pasien untuk mencegah kekambuhan.
\end{abstract}

Kata kunci: renal tubular asidosis; anemia stomatositosis; terapi substitusi

\section{Abstract}

Renal tubular acidosis (RTA) type I is a clinical syndrome caused by failure of urinary acidosis by distal tubule that characterized by metabolic acidosis, hypokalaemia, hyperchloremia, with serum anion gap dan normal glomerular function. Stomacytosis anemia is a type of haemolytic non autoimun anemia caused by dysfunction of erythrocyte membrane that characterized by stomacytocyte in peripheral blood smear. Objective: To reported case RTA type I with Hereditary Stomatositosis Anemia. Case: A case had been reported, woman 30 years old with chief complain weakness of all extremities since 1 day before admission. Patient also have breathlessness, polyuria, polydipsia, paleness and fatigue. this symptom has been felt since 5 years ago. Physical examination: composmentis, blood pressure 120/80 $\mathrm{mmHg}$, heart rate 110x/minute, kusmaull, and anemic. Tetra paresis in motoric examination. ECG: Sinus tachycardia with flat T wave. Laboratory test: $\mathrm{Hb} 88 \mathrm{~g} / \mathrm{dL}$, normocyte normochromic with target cell, stomacytocyte. Potassium $1.7 \mathrm{mmol} / \mathrm{L}$, chloride $122 \mathrm{mmol} / \mathrm{L}$, blood gas analysis with $\mathrm{pH} 7.05$, $\mathrm{HCO}_{3}-6.9 \mathrm{mmol} / \mathrm{L}$. Urinalysis: urinary $\mathrm{pH}$ 6.5, urinary electrolyte potassium $18.2 \mathrm{mmol} / \mathrm{L}$; TTKG 13; serum anion gap 11.4; urinary anion gap 16.2. Patient was treated with potassium and bicarbonate intravenous substitution. After therapy patient was recovered. Conclusion: Need long live potassium and alkali substitution to prevent symptom recurrence.

Keywords: Renal tubular acidosis; stomacytosis anemia; substitution therapy 


\section{PENDAHULUAN}

Renal tubular asidosis adalah suatu sindrom klinik yang disebabkan gangguan reabsorpsi bikarbonat $\left(\mathrm{HCO}_{3}^{-}\right)$di tubulus proksimal atau gangguan pengasaman urine (sekresi ion $\mathrm{H}^{+}$) di tubulus distal dan ditandai oleh asidosis metabolik hiperkloremik, anion gap plasma yang normal dan fungsi glomerulus normal. ${ }^{1}$ Renal tubular asidosis pertama kali dilaporkan pada anak oleh Lightwood dan Butler serta pertama kali dilaporkan pada dewasa oleh Baines. Renal tubular asidosis baru dikenal sebagai kelainan tubulus ginjal berupa gangguan reabsorpsi $\mathrm{HCO}_{3}$ atau gangguan sekresi ion $\mathrm{H}^{+}$oleh Albright pada tahun 1946. Gejala klinik renal tubular asidosis umumnya non-spesifik sehingga sering lolos dari diagnosis dan terlambat atau tidak mendapat pengobatan. $^{2}$

Renal tubular asidosis dapat digolongkan atas empat pembagian yaitu renal tubular asidosis tipe I atau dikenal tipe distal akibat kegagalan pengasaman urine pada tubulus distal, renal tubular asidosis tipe II atau tipe proksimal akibat kegagalan rearbsorpsi $\mathrm{HCO}_{3}$ - pada tubulus proksimal, renal tubular asidosi tipe III atau tipe campuran tipe I-II serta renal tubular asidosis tipe IV yang disebabkan defisiensi aldosteron atau resistensi tubulus distal terhadap aldosteron (pseudoaldosteronisme). ${ }^{2}$

Renal tubular asidosis tipe I memiliki dua penyebab, yakni: primer dan sekunder. Penyebab primer adalah mutasi pada anion exchanger AE1 yang di-encode oleh SLC4A1 (ditemukan pada permukaan basolateral $\alpha$-intercalated cell), mutasi pada a4 atau B1 subunit dari v H+ATPase (ditemukan pada permukaan apical $\alpha$ intercalated cell). ${ }^{3}$ Penyebab sekunder adalah penyakit autoimun (Sindrom Sjogren, lupus, hipergammaglobulinemia, sirosis biliar primer, penyakit tiroid autoimun), toksin (ifosfamid, lithium karbonat, toluene, amphotericin B), nefrokalsinosis, sickle cell disease, transplantasi ginjal (kemungkinan efek toksik dari calcineurin inhibitor), obstruksi kronik saluran kemih, sirosis hepatis. ${ }^{4}$

Renal tubular asidosis tipe I atau tipe distal ini mempunyai karakteristik dengan kegagalan pengasaman pada tubulus distal. Pasien sering datang dengan gejala yang tidak spesifik, minimal atau bahkan tanpa gejala sehingga menyebabkan keterlambatan diagnosis. Dalam perkembangannya, kegagalan pengasaman urine ini akan mempengaruhi keseimbangan asam basa sehingga akan menyebabkan asidosis metabolik hiperkloremik dan hipokalemia berat sehingga akan berakibat fatal. ${ }^{5}$

Prevalensi renal tubular asidosis secara epidemiologi pada populasi umum belum diketahui secara pasti. Beberapa penelitian terkait yang ada hanya pada kelompok tertentu. Penelitian di Thailand memperkirakan prevalensi renal tubular asidosis tipe I ini adalah sekitar 2,8\% dari kejadian renal tubular asidosis itu sendiri. Prevalensi renal tubular asidosis tipe I pada pasien dengan osteopenia di India 
mencapai $22 \%$ dan pada pasien dengan Sindrom Sjogren di Inggris didapatkan prevalensinya mencapai $25 \%{ }^{6}$

Dasar kelainan dari renal tubular asidosis tipe I adalah gangguan sekresi ion $\mathrm{H}^{+}$pada tubulus distal dan gangguan produksi dan ekskresi $\mathrm{NH}_{4}^{+}$. Pembentukan $\mathrm{NH}_{4}{ }^{+}$terjadi di tubulus proksimal dari hasil metabolisme asam amino glutamin yaitu $\mathrm{NH}_{3}+$ glukosa $+\mathrm{CO}_{2}+\mathrm{HCO}_{3}{ }^{-}$. Gugus $\mathrm{NH}_{3}$ yang terbentuk akan berikatan dengan ion $\mathrm{H}^{+}$membentuk $\mathrm{NH}_{4}{ }^{+}$yang selanjutnya bergabung dengan $\mathrm{Cl}^{-}$menjadi $\mathrm{NH}_{4} \mathrm{Cl}$ dan kemudian diekskresi bersama urine. Sedangkan $\mathrm{HCO}_{3}^{-}$yang terbentuk masuk sirkulasi sistemik melalu vena renalis. $\mathrm{NH}_{4}{ }^{+}$ yang tidak keluar bersama urine akan masuk ke hepar melalui sirkulasi sistemik dan di metabolisme menjadi urea menggunakan sejumlah ion $\mathrm{HCO}_{3}{ }^{-1}$ Asidosis metabolik pada renal tubular asidosis tipe 1 disebabkan gangguan sekresi ion $\mathrm{H}^{+}$dan gangguan produksi $\mathrm{HCO}_{3}^{-}$karena produksi $\mathrm{NH}_{4}^{+}$berkurang. Hiperklorinemia terjadi karena gangguan sekresi ion $\mathrm{Cl}^{-}$dalam bentuk $\mathrm{NH} 4 \mathrm{Cl}$. Pada renal tubular asidosis tipe distal, penderita tidak mampu menurunkan $\mathrm{pH}$ urine $<6,0$ selama beban asam dan $<5,5$ selama asidosis sistemik berat. Reabsorpsi $\mathrm{HCO}_{3}{ }^{-}$ umumnya normal, tapi karena $\mathrm{pH}$ urine tinggi $5-15 \% \mathrm{HCO}_{3}{ }^{-}$lolos dari reabsorpsi di tubulus proksimal. ${ }^{1}$ Pembuangan $\mathrm{K}^{+} \mathrm{di}$ urine bersamaan dengan $\mathrm{HCO}_{3}{ }^{-}$ menyebabkan hipokalemia.

Patomekanisme renal tubular asidosis tipe 1 meliputi 3 tipe, yaitu tipe 1 merupakan kelainan sekretorik ketidakmampuan sekresi ion $\mathrm{H}^{+}$pada tubulus distal (tipe klasik), Tipe 2 merupakan kelainan gradien karena ketidakmampuan mempertahankan gradien tinggi lumen vessel karena kebocoran kembali hasil sekresi ion $\mathrm{H}^{+}$, tipe 3 merupakan kelainan dependensi voltase akibat ketidakmampuan mempertahankan potensial negatif lumen distal trans-epitel. ${ }^{7}$

Pengobatan renal asidosis tipe 1 bertujuan mengoreksi asidosis kelainan elektrolit dan asam basa. Suplementasi kalium tanpa memandang kalium plasma diberikan sebelum koreksi asidosis karena hipokalemia berat akan mengganggu otot jantung dan pernafasan. Suplementasi alkali yang berguna untuk mengoreksi asidosis dan mempertahankan ekskresi kalsium pada kadar $\mathrm{HCO}_{3}{ }^{-}$plasma normal yang diberikan seumur hidup. ${ }^{1}$

Anemia stomatosis adalah tipe anemia hemolitik non autoimun yang diakibatkan kelainan pada membran eritrosit yang ditandai dengan ditemukannya stomatosit pada gambaran darah tepi. Stomatositosis merupakan kelainan eritrosit yang jarang yang merupakan kelainan herediter dari membran eritrosit. Pada dasarnya ada 2 grup dari hemolitik non imun herediter anemia yang disebabkan oleh defek pada membran eritrosit. Yang pertama adalah kelainan pada sitoskleleton dari sel darah merah dan yang kedua adalah kelainan pada permeabilitas dari membran eritrosit. $^{8}$ Stomatositosis merupakan kelainan yang terjadi pada permeabilitas membran eritrosit. Penyebab keadaan ini adanya mutasi pada pita 3 dari eritrosit 
anion exchanger protein 1 AE1 dimana ini memegang peranan penting dalam ekspresi struktur dan fungsi dari membran sel darah merah. Selain itu, ini juga bertanggung jawab untuk aktivitas pertukaran ion, transportasi bikarbonat dan ion klorida. ${ }^{9}$

Stomatositosis memiliki 4 tipe utama, yaitu: overhydrated stomatocytosis, dehydrated stomatocytosis, cryohydrocytosis dan familial pseudohyperkalemia. Pada overhydrated stomatocytosis memiliki karakteristik eritrosit yang makrositik dengan peningkatan fragilitas osmotik. Dehydrated stomatocytosis merupakan kelainan autosomal dominan dan lebih banyak ditemukan dibandingkan dengan overhydrated. karakteristik yang ditemukan adalah ditemukannya morfologi yang pleiotrofik; tipe yang hanya menunjukkan sel target dan atau stomatositosis, tipe dengan pseudohiperkalemia, dan tipe dengan pseudohiperkalemia dengan edema perinatal. Total intraseluler $\mathrm{Na}^{+}$dan $\mathrm{K}^{+}$ dalam sel darah merah lebih rendah dibandingkan normal, dan osmotik resisten. Mutasi pada protein P1EZO1 diasosiasikan dengan dehydrated stomatocytosis. ${ }^{8}$

Stomatositosis bisa dikonfirmasi dengan mengukur intra seluler $\mathrm{Na}^{+}$dan $\mathrm{K}^{+}$dengan Flame fotometri. Penurunan fragilitas osmotik didapatkan pada dehydrated hereditary stomatocytosis. Untuk stomatositosis ini sampai saat ini belum ada pemeriksaan yang spesifik. Namun ada tes yang bisa membantu kita dalam mendiagnosis stomatositosis tersebut yaitu EMA-binding test dan tes fragilitas osmotik. ${ }^{10}$

\section{LAPORAN KASUS}

Dilaporkan seorang pasien wanita 30 tahun datang dengan keluhan utama lemah keempat anggota gerak sejak 1 hari sebelum masuk rumah sakit. Pasien juga mengeluhkan sesak nafas, dimana sesak nafas tidak bertambah dengan aktivitas, perubahan posisi, serta riwayat paroxysmal nocturnal dyspnea tidak ada. Pasien juga mengeluhkan sering buang air kecil dengan jumlah yang banyak dan pasien juga banyak minum. Keluhan pucatpucat dan lemah letih juga dikeluhkan oleh pasien. Keluhan demam, nyeri sendi, rambut rontok, fotofobia, mulut kering dan mata merah dan gatal, serta sembabsembab tidak ada. Pasien juga tidak mengeluhkan adanya perdarahan gusi, menstruasi memanjang, lebam-lebam pada kulit serta perdarahan saluran cerna. Pasien telah menikah dan memiliki 2 orang anak. Tidak ada riwayat hipertensi, riwayat penyakit hipertiroid, diabetes melitus, keguguran, penyakit jantung, sirosis hepatis, dan tidak ada riwayat penyakit alergi dan autoimun sebelumnya. Riwayat trauma kepala, tulang punggung serta kejang tidak ada. Riwayat pengobatan kemoterapi, jamur, epilepsi tidak ada. Dari riwayat pasien, pasien juga telah mengalami keluhan yang sama berulangulang sejak 5 tahun yang lalu namun 
pengobatan tidak pernah tuntas oleh pasien.

Pemeriksaan fisik keadaan umum baik, kesadaran compos mentis cooperative, tekanan darah $120 / 80 \mathrm{mmHg}$, nadi 110 kali/menit, suhu $36,5^{\circ} \mathrm{C}$ dan konjungtiva anemis. Pemeriksaan paru dan jantung dalam batas normal. Pada ekstremitas didapatkan motorik: 333/333, sensorik: sensibilitas halus dan kasar baik. Pemeriksaan refleks didapatkan refleks fisiologis menurun dan refleks patologis tidak ada. Pemeriksaan abdomen: tidak ada pembesaran hepar dan lien.

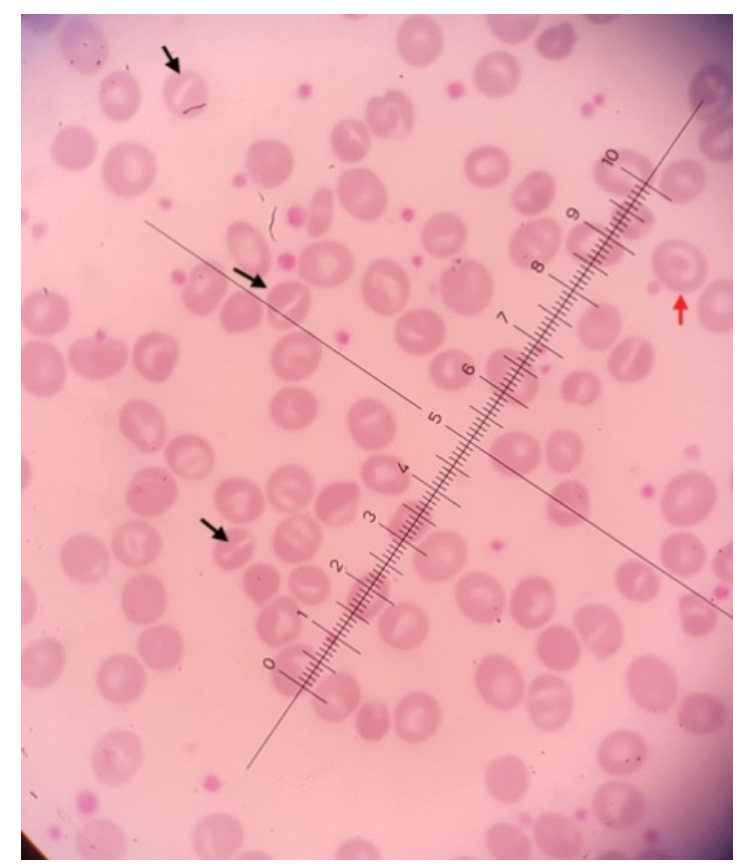

Gambar 1. Gambaran darah tepi stomatosit (panah hitam: stomatosit, panah merah : sel target).

Pemeriksaan laboratorium didapatkan $\mathrm{Hb}$ 8,8 $\mathrm{g} / \mathrm{dL}$ dengan $\mathrm{MCV} / \mathrm{MCH} / \mathrm{MCHC}$ : 92/30/33, gambaran darah tepi normositik normokrom dengan sel target $(+)$ dan sel stomatosit $(+)$. Darah rutin lainnya didapatkan jumlah leukosit $8.700 / \mathrm{mm}^{3}$ dengan hitung jenis $0 / 0 / 1 / 77 / 15 / 7$, jumlah trombosit $240.000 / \mathrm{mm}^{3}$ serta retikulosit $3,4 \%$. Ureum $40 \mathrm{mg} / \mathrm{dL}$, kreatinin 1,1 $\mathrm{mg} / \mathrm{dL}$. Elektrolit darah: Natrium $144 \mathrm{mmol} / \mathrm{L}$; Kalium 1,7 mmol/L; klorida $122 \mathrm{mmol} / \mathrm{L}$; dan analisa gas darah: $\mathrm{pH}$ 7,05; $\mathrm{pCO}_{2} 25 \mathrm{mmHg} ; \mathrm{pO}_{2} 174 \mathrm{mmHg}$; BEEcf -23,6; $\mathrm{HCO}_{3}^{-}$6,9 mmol/L. Pada pemeriksaan osmolaritas serum didapatkan hasil $307 \mathrm{mOsmol} / \mathrm{kgH}_{2} \mathrm{O}$. Pemeriksaan gula darah puasa $90 \mathrm{mg} / \mathrm{dL}$ dan gula darah 2 jam post-prandial 100 $\mathrm{mg} / \mathrm{dL}$. Pemeriksaan fungsi tiroid didapatkan TSH 2,3 mIU/L dan FT4 0,9 ng/dL. Pemeriksaan serum ALT/AST 30/34 $\mathrm{u} / \mathrm{L}$ Untuk pemeriksaan urine didapatkan $\mathrm{pH}$ urine 6,5; berat jenis urine 1,010; leukosit 0-1; eritrosit 0-1; protein (-). Pemeriksaan elektrolit urine didapatkan hasil Kalium 18,2 mmol, Natrium 149 mmol, Klorida $151 \mathrm{mmol}$, osmolaritas urine $246 \mathrm{mOsmol} / \mathrm{kgH}_{2} \mathrm{O}$. Didapatkan juga Anion gap serum 11,4, anion gap urine 16,2 dan trans-tubular creatinine gradient (TTKG) 13. Pemeriksaan ANA profile didapatkan RNP/Sm (-), SS-A native (-), Ro52 recombinant (-), SS-B (-) yang menunjukkan tidak ada kemungkinan Sindrom Sjogren. Pemeriksaan uji Coomb didapatkan hasil indirek (-) dan direk (-). Pada pemeriksaan EKG didapatkan gambaran sinus takikardia dengan gelombang $\mathrm{T}$ yang mendatar. Pada pemeriksaan ultrasonografi ginjal didapatkan hasil sonogram kedua ginjal dalam batas normal. Dari hasil tersebut pasien kita diagnosis dengan Renal Tubular Asidosis tipe I dengan anemia sedang 
normositik normokrom et causa hemolitik non-autoimun et causa stomatositosis.

Pasien diterapi dengan IVFD $\mathrm{KCl} 40 \mathrm{mEq}$ dalam $200 \mathrm{cc} \mathrm{NaCl}$ 0,9\% habis dalam 8 jam dan IVFD bikarbonat $250 \mathrm{mEq}$ dalam D5\% 500 cc habis dalam 8 jam. Setelah diberikan terapi awal, pasien mengalami perbaikan, fungsi motorik membaik dan sesak nafas perbaikan. Untuk terapi pemeliharaan pasien diberikan tablet kalium 3x600mg, dan bikarbonat 3x500mg per oral. Untuk anemia tidak diberikan terapi khusus dan hanya dilakukan pemantauan nilai $\mathrm{Hb}$ dan fungsi hemodinamika.

Setelah 2 hari perawatan pasien mengalami perbaikan yang ditandai dengan klinis perbaikan dengan $\mathrm{pH}$ darah, kenaikan kadar bikarbonat dan kalium dalam serum. Sedangkan $\mathrm{Hb}$ masih dalam kadar yang sama, namun kita hanya melakukan pemantauan karena tidak mengganggu hemodinamika. Pasien kemudian dipulangkan dengan pemberian suplementasi kalium dan bikarbonat oral seumur hidup untuk mencegah kekambuhan.

\section{PEMBAHASAN}

Telah dilaporkan pasien wanita 30 tahun dengan diagnosis renal tubular asidosis tipe I dengan anemia sedang normositik normokrom et causa hemolitik non autoimun et causa stomatositosis. Diagnosis RTA tipe I ditegakkan berdasarkan riwayat lemah anggota gerak yang berulang, sesak nafas, pernafasan Kusmaul dengan tetraparesis.
Laboratorium: hipokalemia, hiperkloremia, asidosis metabolik, $\mathrm{pH}$ urine $>6,0$ dan anion gap urine positif.

Renal tubular asidosis tipe I pada pasien, kita duga merupakan penyebab primer, dimana kita telah menyingkirkan untuk penyebab sekunder seperti penyakit autoimun (Sindrom Sjogren), keadaan hipertiroid, penggunaan obat-obatan seperti; ifosfamid, lithium karbonat, toluene, amphotericin $B$, pada ultrasonografi ginjal tampak kedua ginjal dalam batas normal. Namun untuk pemeriksaan lebih pasti dapat dilakukan pemeriksaan mutasi pada anion exchanger-1 yang dikode gen SLC4A1 pada kromosom $17 .^{1}$

Pengobatan pada RTA tipe I bertujuan untuk mengoreksi asidosis metabolik dan kelainan elektrolit. Suplementasi alkali diberikan seumur hidup pasien untuk mencegah asidosis berulang. Keadaan asidosis metabolik kronik bisa menimbulkan nefrokalsinosis hingga terjadi penyakit ginjal tahap akhir. ${ }^{1}$ Suplementasi kalium pada pasien ini juga diberikan seumur hidup pasien untuk mencegah kekambuhan. Edukasi untuk pasien ini adalah untuk mengetahui gejalagejala hipokalemia, sehingga dapat diminimalisir komplikasi yang berat. Selain itu pemahaman yang tepat mengenai preventif untuk hipokalemia juga diperlukan. Pasien perlu mengetahui bahwa konsumsi karbohidrat tinggi dapat memicu hipokalemia. Stres fisik dan psikologis juga memicu hormon adrenokortikoid yang dapat berefek terjadi 
hipokalemia. Untuk seterusnya pasien juga perlu mengetahui bahwa dia mesti mengonsumsi kalium dan bikarbonat seumur hidup dan perlu untuk kontrol rutin untuk pemeriksaan fungsi ginjal untuk mencegah perkembangan penyakit menjadi penyakit ginjal tahap akhir. ${ }^{7}$

Terapi yang kita berikan pada pasien ini adalah koreksi Kalium dan bikarbonat parenteral karena hipokalemia pada pasien tergolong pada hipokalemia berat yang ditandai dengan kalium serum $<2 \mathrm{mmol} / \mathrm{L}$ dan kelainan pada EKG yaitu gelombang $T$ yang mendatar. ${ }^{6}$ Jika kita tidak mengoreksi kemungkinan bisa timbul aritmia pada pasien. Aritmia berupa timbulnya fibrilasi atrium, ventrikuler takikardi merupakan efek hipokalemia pada otot jantung. ${ }^{7} \mathrm{Hal}$ ini terjadi akibat perlambatan repolarisasi ventrikel pada keadaan hipokalemia yang menimbulkan peningkatan arus rientri. ${ }^{1}$

Diagnosis anemia sedang ec. hemolitik non autoimun ec. stomatositosis berdasarkan anamnesis pucat-pucat, keluhan lemah letih tanpa adanya riwayat perdarahan. Hasil laboratorium: $\mathrm{Hb}$ 8,8 g/dL dengan gambaran darah tepi: stomatosit (+), sel target $(+)$, retikositosis, uji Coomb (-) serta serum ALT/AST yang normal. Stomatositosis sendiri memiliki 4 tipe utama yaitu: overhydrated stomatocytosis, dehydrated stomatocytosis, cryohydrocytosis, dan familial pseudohyperkalemia. Untuk membedakan tipe tersebut, dapat dilakukan pemeriksaan EMA-binding test dan tes fragilitas osmotik serta menghitung $\mathrm{Na}^{+}$ dan $\mathrm{K}^{+}$intra sel dengan flame photometry. ${ }^{8}$ Namun karena keterbatasan sumber daya, kita tidak dapat melakukan pemeriksaan tersebut. Tidak ada terapi spesifik pada kasus ini, hanya dilakukan pemantauan nilai $\mathrm{Hb}$ dan fungsi hemodinamika. Indikasi transfusi jika didapatkan nilai $\mathrm{Hb}<8 \mathrm{~g} / \mathrm{dL}$ serta adanya gangguan hemodinamika seperti adanya bising fungsional pada jantung dan anemia heart disease.

Seperti yang kita singgung tadi, penyebab RTA tipe I pada pasien ini setelah disingkirkan penyebab lain diduga adalah tipe primer dengan kemungkinan mutasi pada anion exchanger AE1 yang di-encode oleh SLC4A1. Mutasi pada kromosom tersebut akan menyebabkan gangguan sekresi ion $\mathrm{H}^{+}$dan $\mathrm{NH}_{4} \mathrm{Cl}$ dimana hal ini akan menyebabkan gangguan pengasaman urine pada segmen kortikal dan medular tubulus distal. Mutasi pada anion exchanger AE1 yang dikode oleh SLC4A1 terjadi pada pita ke 3 dari SLC4A1. Kromosom tersebut juga mengkode eritrosit anion exchanger protein 1 AE1 yang nantinya mengekspresikan struktur dan fungsi dari membran eritrosit. Keadaan mutasi tersebut akan menyebabkan perubahan potensial membran eritrosit sehingga akan menyebabkan deformitas pada eritrosit yang kita kenal sebagai bentuk stomatosit. Stomatosit itu sendiri merupakan bentuk yang fragile dan mudah hancur melewati sistem retikuloendotelial. ${ }^{7}$

Kejadian RTA tipe I dan stomatositosis pada pasien ini bukan suatu koinsiden karena terjadi mutasi pada kromosom 
yang sama. Mutasi tersebut bersifat autosomal dominan dan pada beberapa literatur disebutkan bahwa manifestasi klinis biasanya tidak terlalu berat dan bisa baru dikeluhkan pada usia dewasa. Tumbuh kembang pada individu tersebut biasanya normal dan jarang terjadi onset dini dari penyakitnya. Penyebab dari mutasi tersebut belum diketahui sampai saat ini. ${ }^{1}$

Untuk berikutnya pasien dan keluarga diedukasi untuk selalu mengonsumsi suplemen kalium dan bikarbonat serta perlu mencegah hal-hal yang bisa mencetuskan hipokalemia. Selain itu pasien mesti kontrol teratur, untuk mencegah kekambuhan, serta progresivitas penyakit menjadi penyakit ginjal tahap akhir. Perlu dilakukan deteksi dini pada kedua anak pasien untuk gangguan yang sama, mengingat mutasi yang terjadi bersifat autosomal dominan.

\section{SIMPULAN}

Telah dilaporkan seorang wanita 30 tahun dengan diagnosis RTA tipe I, anemia sedang, normositik normokrom ec hemolitik non autoimun ec stomatositosis. Diberikan terapi $\mathrm{KCl} 25 \mathrm{mEq}$ IV dan Bicnat 300 mEq IV dilanjutkan KSR 3×600 mg dan Bicnat $3 \times 500 \mathrm{mg}$ oral. Dua hari perawatan keadaan pasien membaik dengan $\mathrm{pH}$ darah, bikarbonat dan kalium serum normal. Sedangkan hasil $\mathrm{Hb}$ masih dalam nilai yang sama, namun hanya dilakukan pemantauan arena tidak mengganggu hemodinamika pasien. Perlu suplemen kalium dan bikarbonat seumur hidup untuk mencegah kekambuhan dan progresivitas penyakit menjadi penyakit ginjal tahap akhir.

\section{DAFTAR PUSTAKA}

1. Both T, Zietse R, Hoorn EJ, van Hagen PM, Dalm VA, van Laar JA, et al. Everything you need to know about distal renal tubular acidosis in autoimmune disease. Rheumatol Int. 2014; 34(8):103745. doi: 10.1007/s00296-014-2993-3. [PubMed].

2. Yaxley J, Pirrone C. Review of the diagnostic evaluation of renal tubular acidosis. Ochsner J. 2016; 16(4):525-30. [PMC free article].

3. Alper SL. Familial renal tubular acidosis. J Nephrol. 2010; 23(Suppl.16):557-76. [PubMed].

4. Kraut JA, Madias NE. Metabolic acidosis: pathophysiology, diagnosis and management. Nat Rev Nephrol. 2010; 6(5):274-85. doi: 10.1038/nrneph.2010.33. [PubMed].

5. Reddi AS. Interpretation of urine electrolytes and osmolality. In: Fluid, Electrolyte and Acid-Base Disorders. Cham: Springer; 2018. doi: 10.1007/978-3-319-60167-0 2.

6. Palazzo V, Provenzano A, Becherucci F, Sansavini G, Mazzinghi B, Orlandini V, et al. The genetic and clinical spectrum of a large cohort of patients with distal renal tubular acidosis. Kidney Int. 2017; 91(5):1243-55. doi: 10.1016/j.kint.2016.12.017.

7. Vasquez-Rios G, Westrich Jr DJ, Philip I, Edwards JC, Shieh S. Distal renal tubular acidosis and severe hypokalemia: a case report and review of the literature. Journal of Medical Case Reports. 2019; 13:103-10. doi: 10.1186/s13256-019-2056-1. 
8. King MJ, Zanella A. Hereditary red cell membrane disorder and laboratory diagnostic testing. Int J Lab Hematol. 2013; 35(3):237-43. doi: 10.1111/ijlh.12070. [PubMed].

9. Barcellini W, Bianchi P, Fermo E, Imperiali FG, Marcello AP, Vercellati C, et al. Hereditary red cell membrane defects: diagnostic and clinical aspects. Blood Transfus. 2011; 9(3):274-77. doi: 10.2450/2011.0086-10. [PMC free article].

10. Gallagher PG. Abnormalities of the Erythrocyte Membrane. Pediatr Clin North Am. 2013; 60(6):1349-62. doi: 10.1016/j.pcl.2013.09.001. [PMC free article]. 